\title{
Genetic diversity of spineless Cereus jamacaru accessions using morphological and molecular markers
}

\author{
F.I.C. Oliveira ${ }^{1}$, P.N. Bordallo ${ }^{2}$, A.C.R. Castro ${ }^{2}$ and D. Correia ${ }^{2}$ \\ ${ }^{1}$ Departamento de Fitotecnia, Universidade Federal do Ceará, \\ Campus do Pici, Fortaleza, CE, Brasil \\ ${ }^{2}$ Embrapa Agroindústria Tropical, Fortaleza, CE, Brasil \\ Corresponding author: P.N. Bordallo \\ E-mail: patricia.bordallo@embrapa.br
}

Genet. Mol. Res. 12 (4): 4586-4594 (2013)

Received January 30, 2013

Accepted July 1, 2013

Published October 17, 2013

DOI http://dx.doi.org/10.4238/2013.October.17.1

\begin{abstract}
This is the first study to examine the genetic diversity of mandacaru cactus (Cereus jamacaru P. DC.). Plants of spineless mandacaru are commonly found in gardens and parks of urban areas in northeastern Brazil. In addition to exploring their ornamental potential, morphological, and genetic characterization may contribute to the development of plant materials that can be used as a source of macromolecules of potential economic interest. The goal of this study was to estimate the genetic variability of spineless mandacaru accessions using random amplified polymorphic DNA (RAPD) and inter-simple sequence repeat (ISSR) molecular markers, and to characterize their morphology. Ten samples of newly emitted shoots with differentiated areolas and ribs were collected from each accession from the Cactaceous Germplasm Collection of Embrapa Agroindústria Tropical, in Fortaleza, CE. Shoot shape and aspects of spine primordia (presence, location, grouping, and size of spines) were evaluated. The morphological analysis showed that the spineless mandacaru presented spine primordia. Twenty-six RAPD and 15 ISSR primers were polymorphic. A total
\end{abstract}


of 262 markers were obtained, 129 of which were polymorphic. The average polymorphism of ISSR markers was higher than that of RAPD markers. The dendrograms for both analyses showed differentiation between accessions. Nevertheless, the molecular markers detected higher levels of diversity and a different pattern of diversity than those found using morphological markers. The molecular results revealed significant genetic variability both within and between groups.

Key words: Mandacaru; Genetic variability; RAPD; ISSR; Morphology

\section{INTRODUCTION}

The mandacaru, Cereus jamacaru P. DC. (Cactaceae, subfamily Cactoideae, group Cereoideae), is a typical cactus of the Cereus genus, which is composed of tree or shrub plants with erect stems. As the word 'cereus' means 'torch' in both Greek and Latin, this genus was likely named due to the candelabrum shape of the first described cactus (Davet, 2005). Plants of this species are commonly found in northeast Caatinga in Brazil. In this biome, mandacaru is a key species for sustainability and biodiversity conservation (Cavalcanti and Resende, 2006), being an important source of water and nutrients in the dry season. In the semi-arid areas of Brazil, mandacaru stems are used as feed for cattle after removal of spikes by fire, especially in the driest years (Britton and Rose, 1963; Medeiros et al., 1994). Moreover, mandacaru is also used as an ornamental plant (Lima, 1996), since its columnar shape stands out in the landscape. In addition to its use as an ornamental plant, this species is a rich source of macromolecules, including cellulose, hemicellulose, pectin, and other chemical constituents. These macromolecules may have several applied uses, such as raw material for the production of dietary fibers, industrial pectin, bioadhesives, biopolymer film, ethanol, biogas, cellulose nanocrystals, and nanocomposites.

Spineless mandacaru plants are found in states of the Brazilian northeastern region (Cavalcanti and Rezende, 2006), where they are used as ornamental plants (Sampaio et al., 2001) and are commonly found in gardens and parks of urban areas. The lack of information about its origin or the morphological and molecular characteristics of these spineless plants makes it difficult to select promising parents that would have high genetic divergence for the generation of heterotic hybrids. Thus, studies on genetic diversity and morphological characterization are necessary in order to help future breeding programs of spineless mandacaru.

Characterization of species and cultivars can be performed based on morphological differences of plants or differences in the molecules of protein and DNA (Ferreira and Grattapaglia, 1998). The choice of the method used will depend on the available techniques and genetics of the species (Andrade et al., 2009). Morphological descriptors have been used in the identification of varietal and genetic purity (Ambiel et al., 2008), as well as for germplasm characterization. Despite the existence of more advanced techniques, these descriptors are more accessible and form the basis for the application of more sophisticated tools, such as molecular markers (Andrade et al., 2009).

Even though spineless mandacaru all look similar, they may have relevant physiological, molecular, and even morphological differences that are difficult to detect. Molecular markers of DNA are usually used in studies of genetic diversity since they allow the detection of genetic polymorphism without environmental influences, and at any stage of plant develop- 
ment or from cultures of cells or tissues (Faleiro, 2007). Thus, these markers may serve as a tool to help identify species that are difficult to distinguish from each other morphologically. Random amplified polymorphic DNA (RAPD) molecular markers are among the most widely used because it is a simple technique that is relatively low in cost (Huff et al., 1993). Intersimple sequence repeat (ISSR) molecular markers were developed due to the need of exploring microsatellite repeats without the use of DNA sequencing (Zietkiewicz et al., 1994).

Given the potential value of molecular markers and morphological characterization in assessments of diversity, the goal of this study was to estimate the genetic variability using RAPD and ISSR markers, and to morphologically characterize shoots of spineless mandacaru (C. jamacaru) accessions from the Cactaceous Germplasm Collection of Embrapa Agroindústria Tropical. This is the first study to evaluate the genetic diversity of spineless mandacaru using molecular markers.

\section{MATERIAL AND METHODS}

\section{Plant material}

Ten accessions of spineless mandacaru were evaluated in this study (PC53, PC57, PC59, PC116, PC117, PC144, PC167, PC184, PC185, and PC212) that were all obtained from the Cactaceous Germplasm Collection of Embrapa Agroindústria Tropical, and collected in the States of Ceará, Paraíba, and Rio Grande do Norte, in Brazil. The propagules collected, considered as minimal units for morphological evaluation, were vegetatively propagated and maintained in a greenhouse at Embrapa Agroindústria Tropical, in Fortaleza, CE.

\section{Estimate of morphological variability}

Three newly emitted shoots with differentiated halos and ribs were collected per accession, and 20 areolas per shoot were analyzed. The shape of shoot and the appearance of areola were evaluated. Spines (when present) were characterized regarding their presence, location, grouping, and size.

The shape of the shoot was determined with respect to size and diameter, measured with a ruler and digital pachymeter, respectively. Each shoot was subjected to analysis under a stereomicroscope at the time when trichomes were removed from areolas using a hypodermic syringe with the tip bent, and photographs were taken.

Subsequently, qualitative data regarding the presence, position, grouping, prominence, and number of primordia in areolas and shoot shape were categorized numerically, being assigned a number to each code of each trait. The numerical techniques used included the unweighted pair group method with arithmetic mean (UPGMA) using the arithmetic complement of the Jaccard similarity coefficient. The GENES-computational application in genetics and statistics program (Cruz, 2006) was used to generate distance matrices and construct the dendrogram. The cut-off point was estimated using the average distances between all accessions.

\section{Estimate of genetic variability}

Root samples of three plants per accession were collected and stored in liquid nitrogen 
for DNA extraction using the protocol described on Doyle and Doyle (1990). The extracted DNA was subjected to electrophoresis on $1.0 \%$ agarose gel in TBE buffer $(90 \mathrm{mM}$ Tris, 89 $\mathrm{mM}$ boric acid, $2 \mathrm{mM}$ EDTA), and then analyzed under ultraviolet light after ethidium bromide staining. Quantification and purity of DNA were evaluated in a Nanodrop 2000 (Thermo Scientific) system. DNA samples were then diluted to $10 \mathrm{ng} / \mu \mathrm{L}$ and stored at $-20^{\circ} \mathrm{C}$.

The polymerase chain reaction (PCR) amplifications were performed using 23 ISSR primers (I811, I812, I818, I820, I825, I826, I828, I829, I830, I835, I836, I846, I847, I848, I855, I858, I859, I860, I861, I873, I874, I888, and I889; University of British Columbia) and 39 RAPD primers (OPN2, OPN3, OPN5, OPN7, OPN8, OPN17, OPA1, OPA4, OPA6, OPA12, OPAA2, OPAA4, OPAA7, OPAA9, OPAB4, OPAB5, OPAB6, OPAB7, OPAB9, OPO2, OPO4, OPO5, OPO7, OPL2, OPL3, OPL5, OPL7, OPL8, OPL10, OPR1, OPR2, OPR7, OPR8, OPW2, OPW4, OPW5, OPW6, OPW8, and OPW9; Operon Technologies). The ISSR reactions were prepared to a final volume of $25 \mu \mathrm{L}$, containing $1 \mathrm{X}$ PCR buffer, 0.2 $\mathrm{mM}$ of each dNTP, $2 \mathrm{mM} \mathrm{MgCl}, 0.8 \mathrm{mM}$ of each primer, $35 \mathrm{ng}$ DNA, $25 \mathrm{mg}$ bovine serum albumin, and $1 \mathrm{U}$ Taq DNA polymerase. Amplifications were accomplished in a TECHNE TC-512 thermal cycler adjusted to: $94^{\circ} \mathrm{C}$ for 1 min followed by 40 cycles at $94^{\circ} \mathrm{C}$ for $1 \mathrm{~min}$, annealing average temperatures ranging from $44.7^{\circ}$ to $59.6^{\circ} \mathrm{C}$ per min, and $72^{\circ} \mathrm{C}$ for $1 \mathrm{~min}$, with a final extension at $72^{\circ} \mathrm{C}$ for 5 min.

For RAPD reactions, a final volume of $20 \mu \mathrm{L}$ was used, containing $1 \mathrm{X}$ PCR buffer, 0.2 $\mathrm{mM}$ of each dNTP, $2.5 \mathrm{mM} \mathrm{MgCl}_{2}, 0.3 \mathrm{mM}$ of each primer, $35 \mathrm{ng}$ DNA, $60 \mathrm{mg}$ BSA, and $1 \mathrm{U}$ Taq DNA polymerase. Amplifications were performed in a TECHNE TC-512 thermal cycler adjusted to: $96^{\circ} \mathrm{C}$ for $5 \mathrm{~min}$, followed by 45 cycles at $94^{\circ} \mathrm{C}$ for $45 \mathrm{~s}, 35^{\circ} \mathrm{C}$ for $1 \mathrm{~min}$, and $72^{\circ} \mathrm{C}$ for $1 \mathrm{~min}$ and $30 \mathrm{~s}$, concluding with $72^{\circ} \mathrm{C}$ for $7 \mathrm{~min}$. The amplified fragments were separated by electrophoresis on $2.0 \%$ agarose gel in TBE buffer, stained with ethidium bromide, and analyzed under a UV transilluminator. Faint bands were not considered in the analysis.

\section{Data analysis}

The band patterns (markers) of each ISSR and RAPD primer were encoded in a binary sheet based on the presence and absence of bands, designated as 1 and 0 , respectively. The polymorphism of the ISSR and RAPD markers were estimated by calculating the percentage of polymorphic fragments from the total number of amplified fragments. Dendrogram construction was generated from a genetic distance matrix, and UPGMA was used as the clustering method. The mean of the genetic distance matrix was used as the cut-off point of the dendrogram. The optimal number of markers was calculated in order to verify if the number of markers used was appropriate to assess genetic variability. Correlation, sum of squared deviations, and the stress value between the original matrix and samples were used to evaluate the optimal number of markers according to Dias (1998) and Kruskal (1964). The polymorphism produced by each accession was used to determine the genetic distance matrix, based on the Jaccard coefficient. All analyses were conducted using the GENES program (Cruz, 2006).

\section{RESULTS AND DISCUSSION}

\section{Morphological variability}

All of the evaluated accessions of spineless mandacaru presented small spines called 
primordia (Table 1). Some spines could be seen by the naked eye (visual presence). In other accessions, spines were perceived only by touch (tactile presence). Finally, in some accessions, the spines were only detected after total removal of trichomes (occluded presence).

\begin{tabular}{|c|c|c|c|c|c|}
\hline Accession & Primordium presence & Visual & Tactile & Occluded & Place of origin \\
\hline PC53 & Yes & Yes & - & - & Barbalha, CE \\
\hline PC57 & Yes & - & Yes & - & Fortaleza, CE \\
\hline PC59 & Yes & Yes & - & - & Fortaleza, CE \\
\hline PC116 & Yes & - & Yes & - & Maracajaú, RN \\
\hline PC117 & Yes & Yes & - & - & Campina Grande, PB \\
\hline PC144 & Yes & - & Yes & - & Juazeirinho, PB \\
\hline PC167 & Yes & - & - & Yes & Fortaleza, CE \\
\hline PC184 & Yes & - & Yes & - & Fortaleza, CE \\
\hline PC185 & Yes & Yes & - & - & Quixadá, CE \\
\hline PC212 & Yes & - & - & Yes & Monsenhor Tabosa, $\mathrm{CE}$ \\
\hline
\end{tabular}

Removal of trichomes revealed that primordia were located at the basal position. In some shoots, there was a cluster of primordia (Table 2). The number of primordia ranged from 3 to 10 . The occurrence of a single primordium that was more or less prominent in the central part of the grouping was also observed.

Table 2. Position, grouping, prominence, number of primordia in the areola, and shoot shape of 10 accessions of spineless mandacaru (Cereus jamacaru) from the Cactaceous Germplasm Collection of Embrapa Agroindústria Tropical.

\begin{tabular}{llllcl}
\hline Accession & Primordium position & Base grouping & Primordium prominence & Number of primordia & Shoot shape \\
\hline PC53 & Basal & Yes & Not prominent & 4 to 6 & Elliptical \\
PC57 & Basal & Partially & Not prominent & 4 to 6 & Elliptical \\
PC59 & Basal & Yes & Prominent & 4 & Narrow-Elliptical \\
PC16 & Basal & Partially & Not prominent & 4 to 6 & Elliptical \\
PC17 & Basal & Yes & Not prominent & 4 to 7 & Elliptical \\
PC44 & Basal & Yes & Not prominent & 6 to 10 & Elliptical \\
PC67 & Basal & Yes & Slightly prominent & 4 to 6 & Elliptical \\
PC84 & Basal & Partially & Prominent & 3 to 8 & Elliptical \\
PC85 & Basal & Partially & Prominent & 4 to 8 & Elliptical \\
PC12 & Basal & Yes & Slightly prominent & 4 to 8 & Elliptical \\
\hline
\end{tabular}

After numerical categorization, the data were used in a multivariate analysis for the determination of polymorphism among individuals. From this polymorphism, the distance matrix between accessions was determined and then the dendrogram was constructed (Figure $1)$, which presented a cophenetic correlation of 0.81 .

Using the cut-off point ( 0.38$)$ of the dendrogram, four major groups were observed (Figure 1). The first grouping was composed of the PC59 genotype, the second by the accessions PC57, PC116, PC184, and PC185, the third by the genotype PC144, and the fourth group was formed by the accessions PC53, PC117, PC167, and PC212. The groups formed did not allow distinguishing the accessions by geographical origin. The pairs of accessions PC57/ PC116, PC53/PC117, and PC167/PC212 showed no diversity in the characteristics evaluated. The accession PC59 presented the greatest relative distance to the other accessions. 


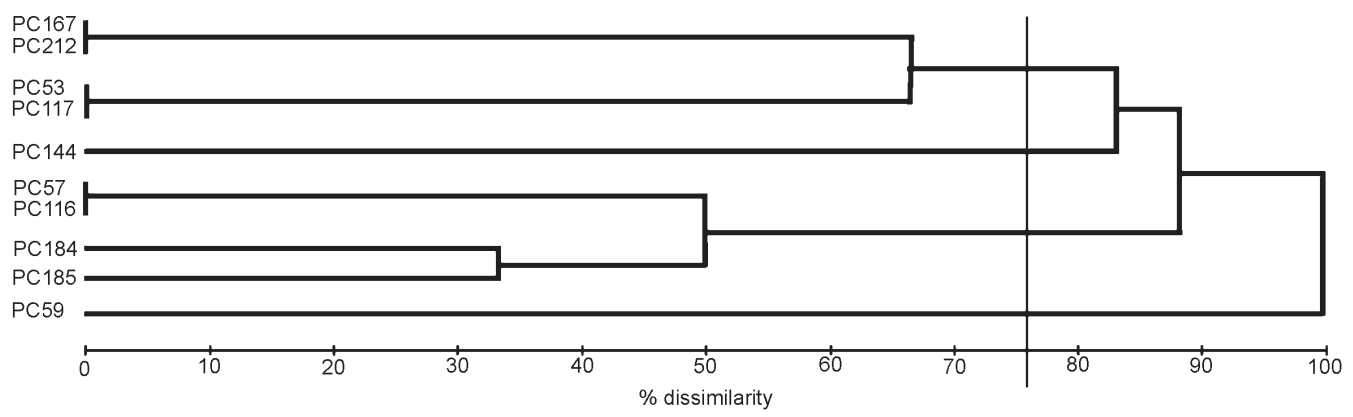

Figure 1. Dendrogram constructed by the unweighted pair-group method using arithmetic averages (UPGMA) based on the Jaccard similarity coefficient from a distance matrix between 10 accessions of spineless mandacaru (Cereus jamacaru) from the Cactaceous Germplasm Collection of Embrapa Agroindústria Tropical, based on morphological data after numerical coding.

\section{Genetic variability}

The extraction protocol used was appropriate to extract DNA of mandacaru (C. jamacaru). The DNA was extracted from mandacaru roots, since these species present little viscous texture, without the high contents of polysaccharides that are present in the cladodes of many other cactus species, which affect DNA extraction (Tel-zur et al., 1999).

From the 39 RAPD primers tested, 26 presented polymorphism (OPA1, OPAA2, OPAA9, OPAB4, OPAB5, OPAB6, OPAB9, OPL2, OPL4, OPL5, OPL7, OPL10, OPN3, OPN5, OPN7, OPN8, OPO2, OPO4, OPO5, OPO7, OPR1, OPR7, OPW2, OPW4, OPW6, and OPW8). Twenty-three ISSR primers were tested, and 15 were polymorphic (I811, I812, I818, I825, I826, I828, I829, I830, I835, I836, I846, I847, I859, I861, and I889).

A total of 262 RAPD and ISSR markers were obtained, 129 (49.2\%) of which were polymorphic. The averages were 7.0 and 5.5 markers per primer for RAPD and ISSR, respectively. Among the RAPD primers, the number of polymorphic bands ranged from 1 (OPAB4 and OPW6) to 9 (OPAB9) and polymorphism ranged from 11.1\% (OPO5) to 80\% (OPN3). For ISSRs, the primers I811 and I861 presented at least five bands per primer, and polymorphism ranged from $28.5 \%$ (I836 and I846) to $100 \%$ (I835 and I861).

The number of markers was considered appropriate to determine genetic diversity. The analysis of the optimal number of markers indicated that, with 91 polymorphic markers, the correlation with the genetic distance matrix of all bands was 0.992 , the sum of squared deviations was 0.031 , and the stress value was 0.048 , which represents a sufficient number of fragments to obtain stable associations among the individuals sampled (Kruskal, 1964; Silveira et al., 2003). The correlation values with genetic distance matrix, sum of squared deviations, stress, and cophenetic correlation found for ISSR and RAPD markers, analyzed alone or grouped, presented similar values, indicating consistency of the results (Table 3).

The polymorphism found from both markers was used for the construction of the genetic distance matrix. The matrix showed that the accession PC57 presented the greatest genetic distance compared to the others, ranging from $55 \%$ in relation to the individual PC117 to $80 \%$ in relation to the genotype PC 212 . The lowest genetic distance was $18 \%$, observed between the accessions PC116 and PC167 (Table 4). 
Table 3. Correlation values with genetic distance matrix, sum of squared deviations, stress, and cophenetic correlation coefficient for the primers RAPD and ISSR, alone or grouped, obtained in the characterization of 10 accessions of spineless mandacaru (Cereus jamacaru) from the Cactaceous Germplasm Collection of Embrapa Agroindústria Tropical.

\begin{tabular}{lcccc}
\hline Primers & Correlation with genetic distance matrix & Sum of squared deviations & Stress value & Cophenetic correlation \\
\hline ISSR & 0.95 & 0.02 & 0.03 & 0.95 \\
RAPD & 0.97 & 0.02 & 0.04 & 0.84 \\
ISSR + RAPD & 0.99 & 0.03 & 0.04 & 0.92 \\
\hline
\end{tabular}

Table 4. Genetic distance matrix among 10 accessions of spineless mandacaru (Cereus jamacaru) from the Cactaceous Germplasm Collection of Embrapa Agroindústria Tropical, generated from 85 RAPD markers and 44 ISSR markers.

\begin{tabular}{|c|c|c|c|c|c|c|c|c|c|c|}
\hline Accession & PC53 & PC57 & PC59 & PC116 & PC117 & $\mathrm{PC} 144$ & PC167 & PC184 & PC185 & PC212 \\
\hline PC53 & 0 & 0.58 & 0.45 & 0.37 & 0.39 & 0.46 & 0.37 & 0.4 & 0.41 & 0.44 \\
\hline PC57 & & 0 & 0.77 & 0.72 & 0.55 & 0.75 & 0.75 & 0.76 & 0.61 & $0.80 *$ \\
\hline PC59 & & & 0 & 0.19 & 0.60 & 0.23 & 0.24 & 0.32 & 0.60 & 0.33 \\
\hline PC116 & & & & 0 & 0.52 & 0.24 & $0.18^{*}$ & 0.19 & 0.50 & 0.22 \\
\hline PC117 & & & & & 0 & 0.61 & 0.59 & 0.57 & 0.46 & 0.62 \\
\hline PC144 & & & & & & 0 & 0.26 & 0.30 & 0.61 & 0.37 \\
\hline PC167 & & & & & & & 0 & 0.27 & 0.54 & 0.27 \\
\hline PC184 & & & & & & & & 0 & 0.57 & 0.29 \\
\hline PC185 & & & & & & & & & 0 & 0.60 \\
\hline PC212 & & & & & & & & & & 0 \\
\hline
\end{tabular}

*Extreme values of genetic distance among the accessions evaluated.

In the dendrogram of genetic dissimilarity constructed from the genetic distance matrix, the cophenetic correlation was 0.92 , a value considered high compared with the minimum 0.60 suggested by Manly (2007) (Figure 2). The average genetic dissimilarity between pairs of accessions was 0.46 , ranging from 0.18 to 0.69 . In the dendrogram generated, the accessions were divided in three main groups, which were not determined by sample locality. The accession PC57, collected in the urban region of Fortaleza, CE, was segregated from the remaining accessions, forming the first group with maximum relative genetic distance between all accessions. The group formed by the accessions PC53, PC117, and PC185, collected in Barbalha, CE, Campina Grande, PB, and Fortaleza, CE, respectively, showed a relative genetic distance of $75 \%$ of the third group, which comprised the remaining accessions.

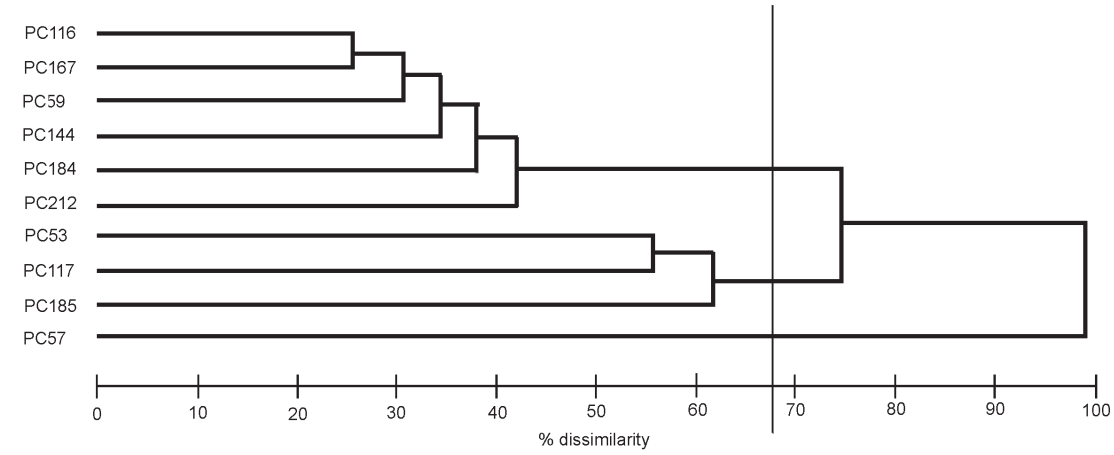

Figure 2. Dendrogram of genetic dissimilarity (UPGMA) of 10 accessions of spineless mandacaru (Cereus jamacaru) from the Cactaceous Germplasm Collection of Embrapa Agroindústria Tropical, obtained based on the Jaccard index, estimated from 85 RAPD markers and 44 ISSR markers. 
The high dissimilarity found between and within the groups formed from the analysis of molecular markers, presented in the dendrogram, the rigor in the selection of bands, and the reliability of results demonstrated by the efficacy tests all indicated that the accessions are genetically distinct. The information generated will be useful for defining the basis for new collections, for improvement of the collection, future breeding programs, and guidance of crosses to explore the heterotic potential of the accessions studied.

\section{Correspondence between morphological and molecular diversity}

The distance matrix obtained from the morphological data was not associated with the genetic distance matrix obtained with the molecular data. In the dendrogram resulting from morphological data, the pairs of accessions PC57/PC116, PC53/PC117, and PC167/PC212 were considered to be duplicates. Conversely, according to the molecular data, no accession was replicated. According to Dillman et al. (1997), this can be explained by genetic interactions, i.e., two different combinations of genes can result in the same phenotype. Furthermore, the number of morphological characteristics evaluated was limited (6) compared with the 129 markers presenting polymorphism. Evidence of the absence of association between morphological variations and polymorphisms of RAPD fragments have previously been reported for clones of other plant species such as Pinus spp and orchids (Phalaenopsis spp) (Chen et al., 1998; Goto et al., 1998).

\section{CONCLUSIONS}

Molecular markers (RAPD and ISSR) and morphological characteristics are effective tools for investigations of diversity among spineless mandacaru accessions. The accessions studied have a wide genetic variability, although there was no correlation between morphological and molecular data.

\section{ACKNOWLEDGEMENTS}

Conselho Nacional de Desenvolvimento Científico e Tecnológico (CNPq) provided one student scholarship, Empresa Brasileira de Pesquisa Agropecuária (Embrapa) provided a student scholarship and a research grant, and Banco do Nordeste do Brasil (BNB) provided a research grant for this study. Research partially supported by MCT/FINEP/SEBRAE.

\section{REFERENCES}

Ambiel AC, Guaberto LM, Vanderlei TM and Machado Neto NB (2008). Agrupamento de acessos e cultivares de três espécies de Brachiaria por RAPD. Acta Sci. Agron. 30: 457-464.

Andrade RA, Lemos EGM, Martins ABG and Paula RC (2009). Caracterização morfológica de plantas de rambutam. Acta Sci. Agron. 31: 613-619.

Britton NL and Rose J (1963). The Cactaceae: Descriptions and Illustrations of Plants of the Cactus Family. 2nd edn. Dover Publications, New York.

Cavalcanti NB and Resende GM (2006). Efeito de diferentes substratos no desenvolvimento do mandacaru sem espinhos (Cereus hildemannianus K. Schum). Rev. Caatinga 19: 255-260.

Chen Y, Hausner G, Kenaschuk E, Procunier D, et al. (1998). Identification of microspore-derived plants in anther culture of flax (Linum usitatissimum L.) using molecular markers. Plant Cell Rep. 18: 44-48. 
Cruz CD (2006). Programa Genes: Biometria. 1st edn. Editora UFV, Viçosa.

Davet A (2005). Estudo Fitoquímico e Biológico do Cacto - Cereus jamacaru De Candolle, Cactaceae. Master's thesis, Universidade Federal do Paraná, Curitiba.

Dias LAS (1998). Análises Multidimensionais. In: Eletroforese de Isoenzimas e Proteínas Afins: Fundamentos e Aplicações em Plantas e Microrganismos (Alfenas AC, ed.). Editora UFV, Viçosa, 405-475.

Dillman C, Bar-Hen A, Guérin D, Charcosset A, et al. (1997). Comparison of RFLP and morphological distances between maize Zea mays L. inbred lines. Consequences for germplasm protection purposes. Theor. Appl. Genet. 95: 92-102.

Doyle JJ and Doyle JL (1990). Isolation of plant DNA from fresh tissue. Focus 12: 13-15.

Faleiro F (2007). Marcadores Moleculares Aplicados a Programas de Conservação e Uso de Recursos Genéticos. Embrapa Cerrados, Planaltina.

Ferreira ME and Grattapaglia D (1998). Introdução ao Uso de Marcadores Moleculares em Análise Genética. 3rd edn. Embrapa Cenargen, Brasília.

Goto S, Thakur RC and Ishii K (1998). Determination of genetic stability in long-term micropropagated shoots of Pinus thunbergii Parl. using RAPD markers. Plant Cell Rep. 18: 193-197.

Huff DR, Peakall R and Smouse PE (1993). RAPD variation within and among natural populations of outcrossing buffalograss [Buchloe dactyloides (Nutt.) Engelm]. Theor. Appl. Genet. 86: 927-934.

Kruskal JB (1964). Multidimensional scaling by optimizing goodness of fit to a nonmetric hypothesis. Psychometrika 29: $1-27$.

Lima JL (1996). Plantas Forrageiras das Caatingas: Usos e Potencialidades. Embrapa Semiárido, Petrolina.

Manly BFJ (2007). Randomization, Bootstrap and Monte Carlo Methods in Biology. 3rd edn. Chapman and Hall, London.

Medeiros J, Sathler MGB and Góis F (1994). Comparação de Diferentes Tipos de Embalagens para o Armazenamento de Sementes de Mandacaru (Cereus jamacaru P. DC.). Boletim Técnico Científico, Mossoró.

Sampaio OB, Oliveira WN, Sonda C, Viegas RA, et al (2001). Propagação Vegetativa de Brotos de Mandacaru sem Espinhos. In: Congresso Nacional de Botânica. Sociedade Botânica do Brasil, João Pessoa, 79.

Silveira SR, Ruas PM, Ruas CF, Sera T, et al. (2003). Assessment of genetic variability within and among coffee progenies and cultivars using RAPD markers. Genet. Mol. Biol. 26: 329-336.

Tel-zur N, Abbo S, Myslabodski D and Mizrahi Y (1999). Modified CTAB procedure for DNA isolation from epiphytic cacti of the genera Hylocereus and Selenicereus (Cactaceae). Plant Mol. Biol. Rep. 17: 249-254.

Zietkiewicz E, Rafalski A and Labuda D (1994). Genome fingerprinting by simple sequence repeat (SSR)-anchored polymerase chain reaction amplification. Genomics 20: 176-183. 